\title{
Modification of Oligolactic Acid with Tetracarboxylic p-tert-Butylthiacalix[4]arene Derivatives: Effect of Macrocyclic Fragment Configuration on Aggregation and Thermal Properties of Copolyesters
}

\author{
Vladimir V. Gorbachuk, ${ }^{a}$ Olga A. Mostovaya, ${ }^{a}$ Vladimir G. Evtugyn, $^{\mathrm{b}}$ Yuri N. Osin, ${ }^{\mathrm{b}}$ \\ Ildar Kh. Rizvanov, ${ }^{c}$ Alexander V. Gerasimov, ${ }^{a}$ and Ivan I. Stoikov ${ }^{a}$ \\ ${ }^{a}$ Kazan Federal University, A.M. Butlerov Chemical Institute, 420008 Kazan, Russian Federation \\ ' Interdisciplinary Center for Analytical Microscopy of Kazan Federal University, 420008 Kazan, Russian Federation \\ ${ }^{\circ}$ A.E. Arbuzov Institute of Organic and Physical Chemistry of KSC RAS, 420088 Kazan, Russian Federation \\ ${ }^{\circledR}$ Corresponding authorE-mail: ivan.stoikov@mail.ru
}

\begin{abstract}
A novel approach to modification of oligolactic acid with three stereoisomers (cone, partial cone, 1,3-alternate) of p-tert-butylthiacalix[4]arene carboxylate derivatives has been developed. Using non-covalent self-assembly in dichloromethane, submicron spherical particles with 701 (cone), 362 (partial cone), 371 nm (1,3-alternate) size were obtained. Nanoprecipitation in the acetone-water mixture allowed forming particles of lower diameter, i.e. 191 (cone), 155 (partial cone) and $98 \mathrm{~nm}$ (1,3-alternate). It was shown by simultaneous thermogravimetry and differential scanning calorimetry that introduction of the macrocyclic fragments into the oligolactic acid increased its thermal stability. The temperature corresponding to the start of thermal decomposition was shifted from $246{ }^{\circ} \mathrm{C}$ (non-modified oligolactic acid) to $263{ }^{\circ} \mathrm{C}$ (that modified with macrocycles in partial cone and cone conformations) and $278{ }^{\circ} \mathrm{C}$ (derivative of 1,3-alternate).
\end{abstract}

Keywords: Thiacalix[4]arene, oligolactic acid, copolyesters, self-aggregation, thermostability.

\section{Модификация олигомолочной кислоты тетракарбоксильными

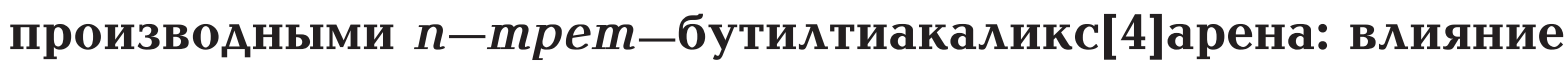 конфигурации макроциклического фрагмента на агрегационные и термические свойства сополиэфиров}

\author{
В. В. Горбачук, ${ }^{\text {a }}$ О. А. Мостовая, ${ }^{a}$ В. Г. Евтюгин, ${ }^{\mathrm{b}}$ Ю. Н. Осин, ${ }^{\mathrm{b}}$ И. Х. Ризванов, ${ }^{\mathrm{c}}$ \\ А. В. Герасимов, ${ }^{a}$ И. И. Стойков ${ }^{a}$ \\ ${ }^{а}$ Казанский (Приволжский) федеральный университет, Химический институт им. А.М. Бутлерова, 420008 Казань, \\ Россия \\ ${ }^{\mathrm{b}}$ Казанский (Приволжский) федеральный университет, Междисциплинарный центр «Аналитическая микроскопия», \\ 420008 Казань, Россия \\ 'Институт органической и физической химии им. А.Е. Арбузова КНЦ РАН, 420088 Казань, Россия \\ ${ }^{\circledR}$ E-mail: ivan.stoikov@mail.ru
}

Реализован подход к модификаџии олигомолочной кислоты стереоизомерами (конус, частичньй конус, 1,3-альтернат) карбоксилатных производных п-трет-бутилтиакаликс[4]арена. С помощью нековалентной самосборки в дихлорметане получены субмикронные сферические частииь с размерами 701 (конус), 362 (частичный конус), 371 нм (1,3-альтернат). Применение метода нанопреципитации в смеси ацетон-вода позволило получить частицы меньшего размера: 191 (конус), 155 (частичный конус) и 98 нм (1,3-альтернат). Совмещённым методом термогравиметрии и дифференцииальной сканирующей калориметрии показано, что 
введение макроциклических фрагментов в олигомолочную кислоту повымает её термостабильность: температура начала разложения возрастает с $246{ }^{\circ} \mathrm{C}$ для немодифицированной олигомолочной кислоть до $263{ }^{\circ} \mathrm{C}$ (модифицированная макроциклами в конфигурациях частичный конус и конус) и $278^{\circ} \mathrm{C}$ (1,3-альтернат).

Ключевые слова: Тиакаликс[4]арен, олигомолочная кислота, сополиэфиры, самоагрегация, термостабильность.

\section{Introduction}

Functionalization of polymer materials with macrocyclic compounds, investigation of the influence of the macrocyclic block geometry on the properties are of unquestionable scientific interest for the supramolecular chemistry, material science, and polymer chemistry. Success in solving this problem leads to development of novel sensor, the drug delivery systems etc. ${ }^{[1-3]}$ High binding selectivity, unique spatial configurations of the macrocyclic compounds together with sufficient stability to environmental factors against biopolymers offer opportunity of their application in various analytic systems including biosensors. Presently, the attention of many researchers is concentrated on the synthesis of various oligo- and polylactic acids. Such a high interest to these compounds is caused by their fast biodegradation that differs them from traditional polymers based on the oil refinery products. ${ }^{[4]}$ Besides, application of oligo- and polylactic acids in biodegradable drug delivery systems seems promising due to no toxicity of their nanoand submicron particles. ${ }^{[5-8]}$ Modified with macrocyclic compound (cyclodextrin), oligolactic acid (OLA) was recently proposed for controlled introduction of antibiotics. ${ }^{[9]}$ Therefore, synthesis of novel classes of the macrocycle modified oligo- and polylactic acids and search for new relationships between the structure of the macrocyclic modifier and the polymer properties offers wide opportunities for developing applicable polymer materials.

(Thia)calix[4]arenes belong to one of the classes of the macrocyclic compounds intensely studied. The relative simplicity of functionalization together with the possibility of pre-determination of the macrocycle configuration by various spatially fixed functional groups led to development of variety of the systems able to recognize various substrates, both neutral and ionic, and their application in the sensor devices. ${ }^{[10-20]}$

Covalent binding of oligolactic acid to the tetracarboxylic derivatives of $p$-tert-butylthiacalix[4]arene, which were in three spatial conformations (cone, partial cone and 1,3-alternate) allowed obtaining novel polymer materials for modification of the glassy carbon electrode surface. ${ }^{[21]}$ Compounds synthesized were found to be promising for design of the sensor devices for recognition of some low-molecular biologically relevant analytes. A distinct effect of the macrocyclic fragment configuration on morphology of the film, which they form on the electrode surface and hence on the appropriate sensor properties indicates significant uniqueness of these copolymers. The above mentioned shows necessity of detailed studying on the effect of the conformation of the macrocyclic modifier of oligolactic acid on its aggregation and thermal properties.

Therefore, present work is related to developing a method for modifying oligolactic acid with p-tert- butylthiacalix[4]arene. Besides, the effect of the macrocyclic block conformation on their aggregation properties and thermal stability of the copolymers obtained was shown.

\section{Experimental}

The ${ }^{1} \mathrm{H}$ and ${ }^{13} \mathrm{C}$ NMR spectra were recorded on a Bruker Avance 400 spectrometer (400.17 MHz for $\mathrm{H}$-atoms) for 3-5 \% solutions in $\mathrm{CDCl}_{3}$. The residual solvent peaks were used as an internal standard.

Elemental analysis was performed on the Perkin-Elmer 2400 Series II instruments.

The IR spectra were recorded on the Spectrum 400 (Perkin Elmer) IR spectrometer.

The mass spectra were obtained on a Bruker Ultraflex III MALDI-TOF instrument. 2,5-Dihydroxybenzoic acid was used as matrix.

For self-assembly, the $0.1 \%(\mathrm{w} / \mathrm{v})$ solutions of non-modified OLA 4 and $p$-tert-butylthiacalix[4]arene modified OLAs 5-7 in acetone and in methylene chloride were prepared.

Nanoprecipitation was performed by dissolving $5 \mathrm{mg}$ of nonmodified 4 or modified oligolactic acid 5-7 in $5 \mathrm{ml}$ of acetone (concentration of the 4-7 was equal to $1 \mathrm{mg} \cdot \mathrm{ml}^{-1}$ ). Then, $5 \mathrm{ml}$ of water were added. After that, acetone was evaporated under agitation with magnetic stirrer, $400 \mathrm{rpm}$, at room temperature $\left(25^{\circ} \mathrm{C}\right)$.

The particle size was determined by the size analyzer of nanoparticles Zetasizer Nano ZS (Malvern) at $20{ }^{\circ} \mathrm{C}$. Solutions and dispersions of the polymers 4-7, obtained by self-assembly or nanoprecipitation method were left for 24 hours after preparation, and thermostated for 2 hours before measurements.

Deionized water with resistivity $>18.0 \mathrm{M} \Omega \cdot \mathrm{cm}$ was used for the preparation of solutions. Deionized water was obtained using a Millipore-Q purification system.

The TEM imaging was carried out with the Hitachi HT7700 Exalens Microscope. $0.1 \%$ solutions were cast on formwar coated nickel grid. Images were processed by ImageJ $1.50 \mathrm{i}$ software for calculation of particle sizes from the images obtained by microscopy method (100-200 particles per microscopy image were used for calculation).

Simultaneous thermogravimetry - differential scanning calorimetry (TG-DSC) was performed using a thermoanalyzer STA 449 C Jupiter (Netzsch) in the argon atmosphere with the total flow rate of $20 \mathrm{ml} / \mathrm{min}$. The temperature rate was equal to $10 \mathrm{~K} /$ min; 10-20 mg of the lactic acid oligomers synthesized were heated in the temperature range of 303-873 K in Pt crucibles. Data were processed with a NETZSCH Proteus software (Marsh procedure).

Oligolactic acid (4). Oligocondensation of lactic acid was performed by heating for 1 hour at $120^{\circ} \mathrm{C}$ and then for 3 hours at $180{ }^{\circ} \mathrm{C}$ and $20-40 \mathrm{mBar}$ on rotary evaporator at $270 \mathrm{rpm}$. El. Anal. Calcd for lactic acid pentamer $\mathrm{C}_{15} \mathrm{H}_{22} \mathrm{O}_{11}, \%$ : $\mathrm{C} 47.62, \mathrm{H}$ 5.86. Found, \%: C 48.34, H 5.75. MS (MALDI), $\mathrm{m} / \mathrm{z}$ : calcd for [M+Na] $]^{+} 401.1$, found 401.2. IR $v_{\max } \mathrm{cm}^{-1}: 3525$ (-OH stretch (free), lit. 3571), 3000 (-CH stretch, asym., lit. 2995), 2961 (-CH stretch, sym., lit. 2944), 1749 ( $-\mathrm{C}=\mathrm{O}$ carbonyl stretch., lit. 1759), 1457 ( $-\mathrm{CH}_{3}$ bend, lit. 1453), 1387, 1362 (-CH deformation including sym. and asym. bend, lit. 1382, 1362), 1211 (-C=O bend, lit. 1268), 1183, 1130, 1089 (C-O- 
stretch, lit. 1194, 1130, 1093), 1045 (-OH bend, lit. 1047), 874, 839 (-C-C- stretch, lit. 926, 868, amorphous), 758 (crystalline). Literary values for absorbtion bands of oligolactic acid were taken from the review on polylactic acid. ${ }^{[4]}{ }^{1} \mathrm{H}$ NMR $\left(400 \mathrm{MHz}, 298 \mathrm{~K}, \mathrm{CDCl}_{3}\right)$ $\delta_{\mathrm{H}}$ ppm: $1.48\left(3 \mathrm{H}, \mathrm{d}^{3} \mathrm{~J}_{\mathrm{HH}}=7.0 \mathrm{~Hz}, \mathrm{CH}_{3} \mathrm{CHC}(\mathrm{O}) \mathrm{OH}\right), 1.57(12 \mathrm{H}$, $\left.\mathrm{m}, \mathrm{CH}_{3} \mathrm{CHC}(\mathrm{O}) \mathrm{O}-\right), 4.36\left(1 \mathrm{H}, \mathrm{q}^{3} \mathrm{~J}_{\mathrm{HH}}=6.8 \mathrm{~Hz}, \mathrm{HO}-\mathrm{CH}\left(\mathrm{CH}_{3}\right)\right), 5.17$ $\left(4 \mathrm{H}, \mathrm{m}, \mathrm{C}(\mathrm{O})-\mathrm{O}-\mathrm{CH}\left(\mathrm{CH}_{3}\right)\right)$.

Modification of oligolactic acid with tetracarboxylic derivative of p-tert-butylthiacalix[4]arene in cone conformation. $4.5 \mathrm{~g}$ of oligolactic acid (4) and $0.5 \mathrm{~g}$ of tetraacid derivative of thiacalix[4]arene 1 were put in the round-bottom flask. The mixture was heated on rotary evaporator at $270 \mathrm{rpm}$, pressure $40 \mathrm{mBar}$, bath temperature $180{ }^{\circ} \mathrm{C}$, for 2 hours until homogenization (the reaction mixture becomes transparent). Then the reaction was continued in the same conditions for additional 10 hours. Mass loss related to removal of water and lactide from reaction mixture was about $1-2 \%$. El. Anal. Calcd for lactic acid pentamer with $5 \%$ of compound $1\left(50\left(\mathrm{C}_{15} \mathrm{H}_{22} \mathrm{O}_{11}\right)+\mathrm{C}_{48} \mathrm{H}_{56} \mathrm{O}_{12} \mathrm{~S}_{4}\right), \%$ : C 48.24, H 5.86, $\mathrm{S}$ 0.65 . Found, \%: C 48.23, H 5.75, S 0.65. MS (MALDI), $\mathrm{m} / \mathrm{z}$ : calcd for $[\mathrm{M}+\mathrm{Na}]^{+}$2416.7, found 2417.0. The IR spectrum corresponded to the spectrum of the oligolactic acid 4. ${ }^{1} \mathrm{H}$ NMR $(400 \mathrm{MHz}$,

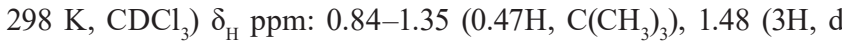
$\left.{ }^{3} J_{\mathrm{HH}}=6.6 \mathrm{~Hz}, \mathrm{CH}_{3}\right), 1.57\left(12 \mathrm{H}, \mathrm{d}^{3} J_{\mathrm{HH}}=6.6 \mathrm{~Hz}, \mathrm{CH}_{3}\right), 4.36(1 \mathrm{H}, \mathrm{q}$ $\left.{ }^{3} J_{\mathrm{HH}}=6.7 \mathrm{~Hz}, \mathrm{HO}-\mathrm{CH}\left(\mathrm{CH}_{3}\right)\right), 5.15\left(4.3 \mathrm{H}, \mathrm{m}, \mathrm{C}(\mathrm{O})-\mathrm{O}-\mathrm{CH}\left(\mathrm{CH}_{3}\right)-\right.$, $\left.\mathrm{OCH}_{2} \mathrm{CO}\right), 6.9-7.8(0.10 \mathrm{H}, \mathrm{m}, \mathrm{Ar}-\mathrm{H}) .{ }^{13} \mathrm{C} \mathrm{NMR}\left(100 \mathrm{MHz}, \mathrm{CDCl}_{3}\right)$ $\delta_{\mathrm{C}}$ ppm: 14.12, 16.63, 20.39, $22.65\left(\mathrm{O}-\mathrm{CH}\left(\mathrm{CH}_{3}\right)-\mathrm{C}(\mathrm{O}) \mathrm{O}-\right), 31.58$ $\left(\mathrm{C}\left(\mathrm{CH}_{3}\right)_{3}\right), 66.76,69.03\left(-\mathrm{O}-\mathrm{CH}\left(\mathrm{CH}_{3}\right)-\right), 169.64(-\mathrm{C}(\mathrm{O}) \mathrm{O}-)$.

Modification of the oligolactic acid with tetracarboxylic derivative of p-tert-butylthiacalix[4]arene in partial cone conformation. $4.5 \mathrm{~g}$ of oligolactic acid (4) in $30 \mathrm{ml}$ of chloroform placed in the round-bottom flask were mixed with $0.5 \mathrm{~g}$ of thiacalix [4] arene tetraacid derivative 2 . Then the flask was fixed on rotary evaporator and the mixture was heated for one hour at atmospheric pressure $\left(180^{\circ} \mathrm{C}, 270 \mathrm{rpm}\right)$. Then reaction mixture was heated in vacuum $\left(180^{\circ} \mathrm{C}, 270 \mathrm{rpm}, 20-40 \mathrm{mBar}\right)$ for 1 hour. Then chloroform was added to reaction mixture again, the procedure of heating under atmospheric pressure with subsequent heating under vacuum was repeated and the reaction mixture was then heated again for the additional 8 hours. Mass loss related to removal of lactide and water from reaction mixture was 3-5\%. El. Anal. Calcd for lactic acid pentamer and $5 \%$ of compound $2\left(50\left(\mathrm{C}_{15} \mathrm{H}_{22} \mathrm{O}_{11}\right)+\mathrm{C}_{48} \mathrm{H}_{56} \mathrm{O}_{12} \mathrm{~S}_{4}\right), \%$ : C 48.24, H 5.86, S 0.65. Found, \%: C 48.06, H 5.73, S 0.61. MS (MALDI), $m / z$ : calcd for $[\mathrm{M}+\mathrm{Na}]^{+} 2416.7$, found 2417.2 . The IR spectrum corresponded to the spectrum of the oligolactic acid 4 . ${ }^{1} \mathrm{H}$ NMR $\left(400 \mathrm{MHz}, 298 \mathrm{~K}, \mathrm{CDCl}_{3}\right) \delta_{\mathrm{H}} \mathrm{ppm}: 1.00-1.35(0.5 \mathrm{H}, \mathrm{m}$, $\left.\mathrm{C}\left(\mathrm{CH}_{3}\right)_{3}\right), 1.47\left(3 \mathrm{H}, \mathrm{d}^{3} J_{\mathrm{HH}}=6.9 \mathrm{~Hz}, \mathrm{CH}_{3}\right), 1.57\left(12 \mathrm{H}, \mathrm{m}, \mathrm{CH}_{3}\right), 1.65-$ $1.75\left(0.1 \mathrm{H}, \mathrm{m}, \mathrm{C}\left(\mathrm{CH}_{3}\right)_{3}\right), 4.35\left(1 \mathrm{H}, \mathrm{q}^{3} \mathrm{~J}_{\mathrm{HH}}=6.9 \mathrm{~Hz}, \mathrm{HO}-\mathrm{CH}\left(\mathrm{CH}_{3}\right)\right.$ ), $5.15\left(4.1 \mathrm{H}, \mathrm{m}, \mathrm{C}(\mathrm{O})-\mathrm{O}-\mathrm{CH}\left(\mathrm{CH}_{3}\right)-, \mathrm{OCH}_{2} \mathrm{CO}\right), 7.1-7.9(0.10 \mathrm{H}, \mathrm{m}$,
Ar-H). ${ }^{13} \mathrm{C}$ NMR $\left(100 \mathrm{MHz}, \mathrm{CDCl}_{3}\right) \delta_{\mathrm{C}} \mathrm{ppm}: 15.80,16.64,16.73$, $20.47\left(\mathrm{O}-\mathrm{CH}\left(\mathrm{CH}_{3}\right)-\mathrm{C}(\mathrm{O}) \mathrm{O}-\right), 31.00$ (br. s., $\left.\mathrm{C}\left(\mathrm{CH}_{3}\right)_{3}\right), 66.73,68.79$, 69.02, 72.48 (-O-CH(CH3)-), 169.56, 169.64, 169.70, 174.53, 175.17 (-C(O)O-).

Modification of oligolactic acid with tetracarboxylic derivative of p-tert-butylthiacalix[4]arene in 1,3-alternate conformation. $4.5 \mathrm{~g}$ of oligolactic acid (4) in $30 \mathrm{ml}$ of chloroform were added in the round-bottom flask to $0.5 \mathrm{~g}$ of thiacalix[4]arene tetraacid derivative 3 . Then the flask was fixed on rotary evaporator and the mixture was heated for one hour at the atmospheric pressure $\left(180{ }^{\circ} \mathrm{C}, 270 \mathrm{rpm}\right)$. Then reaction mixture was heated in vacuum $\left(180^{\circ} \mathrm{C}, 270 \mathrm{rpm}, 20-40 \mathrm{mBar}\right)$ for one 1 hour. After that, chloroform was added to reaction mixture again, the procedure of heating under atmospheric pressure with subsequent heating under vacuum was repeated three times, then the reaction mixture was heated for additional 4 hours. Mass loss related to the removal of the lactide and water from the reaction mixture was $5 \%$. El. Anal. Calcd for lactic acid pentamer and $5 \%$ of compound $3\left(50\left(\mathrm{C}_{15} \mathrm{H}_{22} \mathrm{O}_{11}\right)+\mathrm{C}_{48} \mathrm{H}_{56} \mathrm{O}_{12} \mathrm{~S}_{4}\right), \%$ : C 48.24, H 5.86, $\mathrm{S} 0.65$. Found, $\%$ : C 48.12, H, 5.72, S, 0.63. MS (MALDI), $m / z$ : calcd for $[\mathrm{M}+\mathrm{Na}]^{+}$ 2416.7, $[\mathrm{M}+\mathrm{K}]^{+}$2432.7, found 2417.9, 2432.9. The IR spectrum corresponds to that of the oligolactic acid 4. ${ }^{1} \mathrm{H}$ NMR $(400 \mathrm{MHz}$, $\left.298 \mathrm{~K}, \mathrm{CDCl}_{3}\right) \delta_{\mathrm{H}}$ ppm: $1.15-1.25\left(0.75 \mathrm{H}, \mathrm{m}, \mathrm{C}\left(\mathrm{CH}_{3}\right)_{3}\right), 1.48(3 \mathrm{H}$, $\left.\mathrm{d}^{3} \mathrm{~J}_{\mathrm{HH}}=6.9 \mathrm{~Hz}, \mathrm{CH}_{3}\right), 1.57\left(12 \mathrm{H}, \mathrm{d}^{3}{ }_{\mathrm{HH}}=7.1 \mathrm{~Hz}, \mathrm{CH}_{3}\right), 4.35(1 \mathrm{H}$, $\left.\mathrm{q}^{3} J_{\mathrm{HH}}=6.9 \mathrm{~Hz}, \mathrm{HO}-\mathrm{CH}\left(\mathrm{CH}_{3}\right)\right), 5.15\left(4.3 \mathrm{H}, \mathrm{m}, \mathrm{C}(\mathrm{O})-\mathrm{O}-\mathrm{CH}\left(\mathrm{CH}_{3}\right)-\right.$, $\left.\mathrm{OCH}_{2} \mathrm{CO}\right), 7.3-7.5(0.13 \mathrm{H}, \mathrm{m}, \mathrm{Ar}-\mathrm{H}) .{ }^{13} \mathrm{C} \mathrm{NMR}\left(100 \mathrm{MHz}, \mathrm{CDCl}_{3}\right)$ $\delta_{\mathrm{C}}$ ppm: 14.11, 16.64, 20.39, $22.65\left(\mathrm{O}-\mathrm{CH}\left(\mathrm{CH}_{3}\right)-\mathrm{C}(\mathrm{O}) \mathrm{O}-\right), 31.58$ $\left(\mathrm{C}\left(\mathrm{CH}_{3}\right)_{3}\right), 66.73,68.84,69.02\left(-\mathrm{O}-\mathrm{CH}\left(\mathrm{CH}_{3}\right)\right), 156.4,169.163$ (-C(O)O-).

\section{Results and Discussion}

\section{Synthesis}

For realization of the approach to the OLA modification, stereoisomers of p-tert-butylthiacalix[4]arene carboxylate derivatives macrocycles 1-3 (cone, partial cone, 1,3-alternate) were specified as synthetically available precursors (Scheme 1).

First, the OLA containing five fragments of lactic acid in average was obtained. ${ }^{[21]}$ Synthesis was performed in the rotary evaporator by heating lactic acid up to $120^{\circ} \mathrm{C}$ for one hour in vacuum (30 mBar) with intensive rotation (270 rpm). After that, the temperature was increased

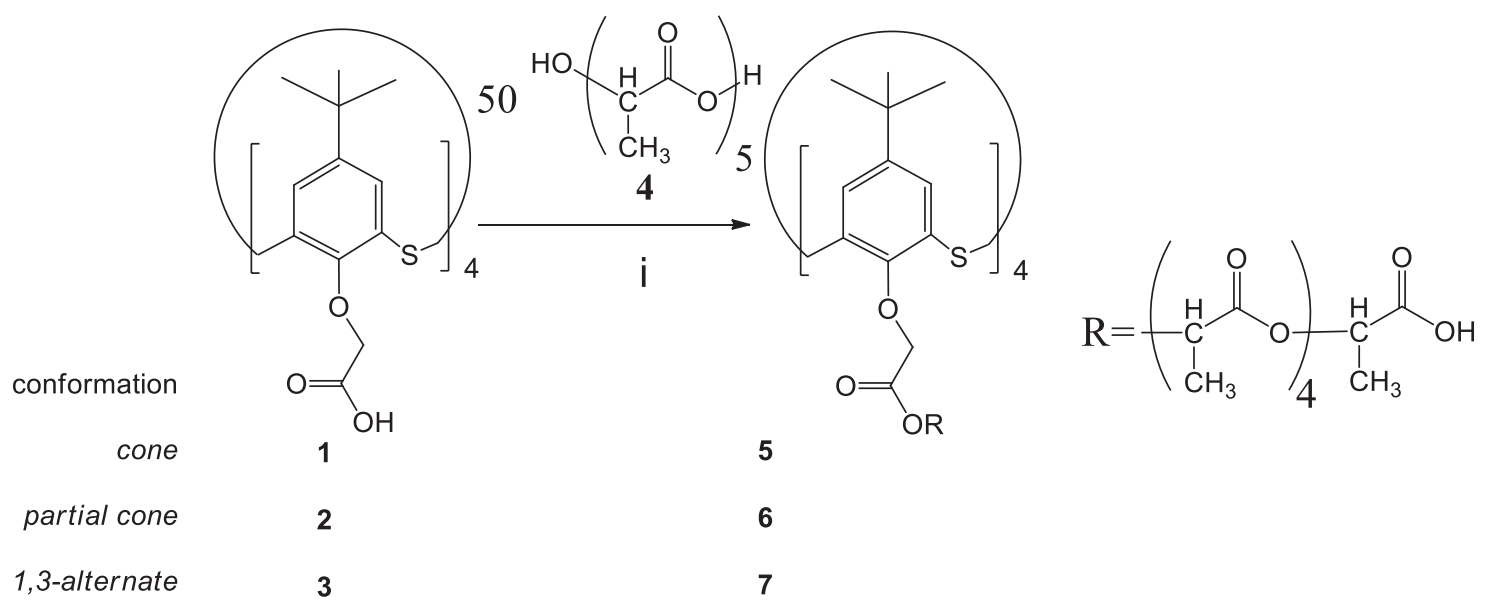

Scheme 1. Reagents and conditions: $180{ }^{\circ} \mathrm{C}, \tau=12 \mathrm{hrs}$ (for 6 and 7 with addition of $\mathrm{CHCl}_{3}$ ), $270 \mathrm{rpm}, \mathrm{P}=20-40 \mathrm{mBar}$. 
to $180{ }^{\circ} \mathrm{C}$ and the mixture was further heated in vacuum within three hours. Quantity of the monomer fragments was estimated by comparing integral intensities of the signals in ${ }^{1} \mathrm{H}$ NMR spectrum. Two overlapping doublets were observed in the spectrum in the field of $1.57 \mathrm{ppm}$ and a doublet with chemical shift $1.48 \mathrm{ppm}$ with ${ }^{3} J_{\mathrm{HH}}=6.4$ and $7.0 \mathrm{~Hz}$, correspondingly, with integral intensity ratio 4:1. They are related to the protons of the OLA methyl groups. Doublet with the chemical shift of $1.48 \mathrm{ppm}$ is related to the methyl group of the ending fragment with free hydroxyl group. In the downfield region of ${ }^{1} \mathrm{H}$ NMR spectrum the signals of methyl group protons at ester fragments and at the terminal carboxylic group are positioned. Quartet in the field of $4.36 \mathrm{ppm}$ with ${ }^{3} \mathrm{~J}_{\mathrm{HH}}=6.8 \mathrm{~Hz}$ is caused by resonance of the $\mathrm{CH}$ group proton of terminal acid fragment with free hydroxyl group. Protons of other four $\mathrm{CH}$ groups appear in the spectrum as a multiplet at $5.17 \mathrm{ppm}$. Ratio of integral intensities of the signals in the fields of 1.57-1.48, 4.36, 5.17 is $15: 1: 4$. This corresponds to pentameric chain structure. Moreover, the composition proposed was confirmed by the MALDI mass-spectrometry data. The peak of molecular ion with $m / z=401.2$ corresponding to the pentamer of lactic acid cationized with sodium ion was observed in the mass spectrum. It should be noted, that the peak of molecular ion was registered on two matrices, i.e. $p$-nitroaniline and 2,5-dihydroxybenzoic acid.

Modification of the oligolactic acid with the thiacalix[4] arene derivatives $\mathbf{1}-\mathbf{3}$, containing four carboxylic groups was performed by copolycondensation method. The OLA obtained was introduced into the reaction with the macrocycles in cone, partial cone and 1,3-alternate conformations. These tetraacid derivatives were taken in the amounts of $5 \%$ of the OLA mass, which corresponded to the molar ratio of 1:50 (the tetraacid to the OLA pentamer).
Copolycondensation with derivative $\mathbf{1}$ in cone conformation was carried out without addition of a solvent because homogenization of the reaction mixture was reached by 1 hour heating at $180{ }^{\circ} \mathrm{C}$. In the case of the macrocycles $\mathbf{2}$ and $\mathbf{3}$, which are in partial cone and 1,3-alternate conformation, chloroform was added for homogenization of the reaction mixture and the reaction was continued at the same temperature. The time, during which copolycondensation is carried out, can affect chain length of the products of the lactic acid condensation ${ }^{[22]}$ and, correspondingly, physical-chemical properties ${ }^{[23]}$ and size of nanoprecipitated particles. ${ }^{[2]}$ Therefore, the synthesis protocol was modified against that published previously. ${ }^{[21]}$ The copolycondensation with all the derivatives of the p-tert-butylthiacalix[4] arene 1-3 was performed at $180{ }^{\circ} \mathrm{C}$ during 12 hours. To confirm esterification of the carboxylic derivatives of $p$-tert-butylthiacalix[4]arene with oligolactic acid, the interaction products were characterized with the MALDI mass-spectrometry. In the mass-spectra of all the products 5-7 (2,5-dihydroxybenzene as matrix) no signals of molecular ions of the oligolactic acid were found while the molecular ion peaks of the thiacalixarene functionalized with oligolactic acid appeared. Probably, it can be explained by more effective ionization of the thiacalixarene derivatives containing the lactic acid fragments (Figure 1).

In the mass-spectra, the peaks of molecular ions corresponded to thiacalixarene derivatives cationized with sodium and potassium ions which contain up to 20 fragments of lactic acid (five lactic acid fragments to each carboxylate group of the thiacalixarene) were observed. The peaks of the molecular ions with higher $\mathrm{m} / \mathrm{z}$ value were present at the noise level. Presence of the molecular ion peak with $m / z=2432.9$ in the mass-spectrum of the product 7 corresponded to its cationization with potassium confirmed

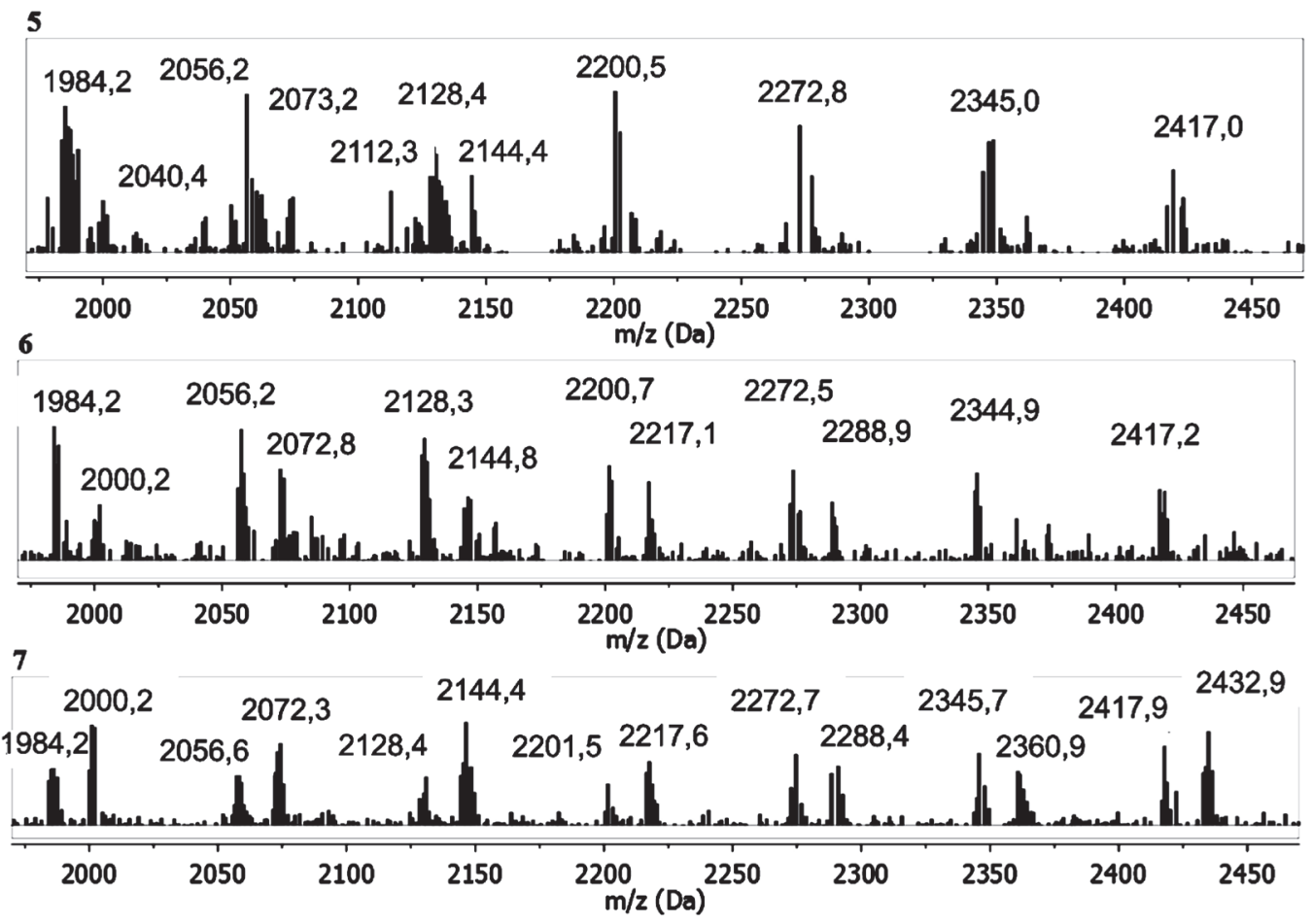

Figure 1. MALDI-TOF mass-spectra of the copolyesters 5-7 obtained in the 2,5-dihydroxybenzoic acid matrix. 
covalent binding and formation of the polyester. In the massspectra, molecular ion peaks with $m / z=2417.0,2417.2,2417.9$ for the copolyesters 5, $\mathbf{6}$ and 7, correspondingly, related to cationization of these structures with sodium were found (Figure 1). Moreover, one can see from the Figure 1, that the mass-spectra contain a number of molecular ion peaks differing from each other by $m / z=72$. They correspond to the products of fragmentation of the copolyesters obtained. These fragment ions can be formed due to successive removal of the lactic acid fragments. ${ }^{[9]}$ Therefore, oligolactic acid was modified with the carboxylic derivatives of the thiacalix[4]arene present in various conformations (cone, partial cone and 1,3-alternate). The structure of the products obtained is confirmed by mass-spectrometry.

\section{Aggregation Behavior of Modified Oligolactic Acid}

Self-assembly study of the copolymers 5-7 (Figure 2) was carried out by dynamic light scattering (DLS). Two algorithms of data analysis were used for determination of the size distribution, i.e. $\mathrm{Z}_{\text {average }}$ determination (intensityaveraged hydrodynamic diameter), and polydispersity index (PdI, ratio of the mean deviation squared to the mean diameter squared). Besides, the particle diameters were calculated by intensity. ${ }^{[25]}$ Results of the measurements show, that most uniform system is formed in dichloromethane due to selfassembly for the OLA modified with cone stereoisomer of thiacalixarene 5 (Table 1). Polydispersity index for the system is equal to $0.23 \pm 0.03$, and the mean hydrodynamic diameter $\mathrm{Z}_{\text {average }}=507 \pm 19 \mathrm{~nm}$. According to the particle size distribution by intensity, the mean diameter of the particles is $701 \pm 45 \mathrm{~nm}$. In the case of partial cone stereoisomer, uniformity of system is lower. Bimodal distribution of the particles by size is observed (micron-sized particles are present). $Z_{\text {average }}$ for 6 is $516 \pm 70 \mathrm{~nm}, \mathrm{PdI}=0.41 \pm 0.1$, particle size is equal to $362 \pm 68 \mathrm{~nm}$ and $4034 \pm 422 \mathrm{~nm}$. In the case of 1,3-alternate stereoisomer 7, only polydisperse systems are formed. $Z_{\text {average }}$ is equal to $879 \pm 193 \mathrm{~nm}, \mathrm{PdI}=0.65 \pm 0.1$, with the particle size of $371 \pm 26 \mathrm{~nm}$ and $5082 \pm 343 \mathrm{~nm}$.

Formation of spherical particles in the self-assembly process was confirmed by transmission electron microscopy (TEM). In the case of non-modified OLA 4, no spheric particles were formed. Particles of minimal size are formed by oligolactic acid 6 modified with thiacalix[4]arene in partial cone conformation $(550 \pm 240 \mathrm{~nm})$. The OLA modification with the cone $\mathbf{1}$ and 1,3-alternate $\mathbf{3}$ macrocycles led to the formation of the particles close in size: for the compound 5, the diameter of particles was 790 $\pm 200 \mathrm{~nm}$ and 770 \pm 360 $\mathrm{nm}$ for the compound 7 (Table 1, Figure 2). However, the compound 7 system was more polydisperse in agreement with the DLS data.

Increase of the solvent polarity (acetone) results in significant changes in aggregation properties of the copolyesters obtained. The oligolactic acid $\mathbf{4}$ is capable to form large aggregates with hydrodynamic diameter of $328 \pm 63 \mathrm{~nm}\left(\mathrm{PdI}=0.26 \pm 0.06, Z_{\text {average }}=404 \pm 50 \mathrm{~nm}\right)$ (Table 1). Polyesters 5-7 modified with thiacalixarenes formed selfassociates of lower diameter than in dichloromethane. It was shown by TEM, the size of the self-associates 5-7 are significantly lower in acetone than in dichloromethane (70$200 \mathrm{~nm}$ depending on the conformation of the macrocyclic fragment) (Table 1, Figure 3).

Nanoprecipitation ${ }^{[26,27]}$ has been found to be more preferred for the formation of homogenous systems. Further increase in solvent polarity (experiments in water) resulted in even more significant decrease in the size of the selfassociates and polydispersity of the colloidal systems. For all three samples 5-7, monodisperse systems were formed

Table 1. The size (Intensity distribution) and PDI of the particles obtained from the DLS results for OLA modified with thiacalix[4]arenes $(1 \mathrm{mg} / \mathrm{ml})$ and TEM.

\begin{tabular}{|c|c|c|c|c|c|c|}
\hline \multirow{2}{*}{ Sample } & \multicolumn{2}{|c|}{ Self-assembly, $\mathrm{CH}_{2} \mathrm{Cl}_{2}$} & \multicolumn{2}{|c|}{ Self-assembly, acetone } & \multicolumn{2}{|c|}{ Nanoprecipitation acetone-water } \\
\hline & DLS & TEM (nm) & DLS & TEM (nm) & DLS & TEM (nm) \\
\hline $\begin{array}{l}\text { Non-modified } \\
\text { OLA } 4\end{array}$ & No particles & No particles & $\begin{array}{c}\mathrm{Z}_{\mathrm{avg}}=404 \pm 50 \mathrm{~nm} \\
\mathrm{D}_{1}=328 \pm 63 \mathrm{~nm}(93 \%) \\
\mathrm{D}_{2}=5083 \pm 268 \mathrm{~nm}(7 \%) \\
\mathrm{PdI}=0.26 \pm 0.06\end{array}$ & $400 \pm 300$ & $\begin{array}{c}\mathrm{Z}_{\text {avg }}=622.5 \pm 357 \\
\mathrm{D}_{1}=619.6 \mathrm{~nm}(100 \%), \\
\mathrm{PdI}=0.8 \pm 0.1\end{array}$ & $400 \pm 150$ \\
\hline $\begin{array}{l}\text { OLA modified } \\
\text { with cone tetraacid } \\
\mathbf{5}\end{array}$ & $\begin{array}{c}\mathrm{Z}_{\text {avg }}=507 \pm 19 \mathrm{~nm} \\
\mathrm{PdI}=0.23 \pm 0.03 \\
\mathrm{D}_{1}=701.4 \pm 45 \mathrm{~nm} \\
(100 \%)\end{array}$ & $790 \pm 200$ & $\begin{array}{c}\mathrm{Z}_{\mathrm{avg}}=433 \pm 27 \mathrm{~nm} \\
\mathrm{PdI}=0.57 \pm 0.08 \\
\mathrm{D}_{1}=405 \pm 36 \mathrm{~nm}(100 \%)\end{array}$ & $70 \pm 20$ & $\begin{array}{c}\mathrm{Z}_{\mathrm{avg}}=181 \pm 2 \mathrm{~nm} \\
\mathrm{PdI}=0.19 \pm 0.02 \\
\mathrm{D}_{1}=191 \pm 11 \mathrm{~nm} \\
\quad(100 \%)\end{array}$ & $150 \pm 50$ \\
\hline $\begin{array}{l}\text { OLA modified } \\
\text { with partial cone } \\
\text { tetraacid } 6\end{array}$ & $\begin{array}{c}\mathrm{Z}_{\text {avg }}=516 \pm 70 \mathrm{~nm} \\
\mathrm{PdI}=0.41 \pm 0.1 \\
\mathrm{D}_{1}=362 \pm 68 \mathrm{~nm} \\
(70 \%) \\
\mathrm{D}_{2}=4034 \pm 422 \mathrm{~nm} \\
\quad(30 \%)\end{array}$ & $550 \pm 240$ & $\begin{array}{c}\mathrm{Z}_{\text {avg }}=261 \pm 120 \mathrm{~nm} \\
\mathrm{PdI}=0.40 \pm 0.17 \\
\mathrm{D}_{1}=251 \pm 81 \mathrm{~nm}(98 \%) \\
\mathrm{D}_{2}=1 \pm 1.5 \mathrm{~nm}(2 \%)\end{array}$ & $200 \pm 100$ & $\begin{array}{c}\mathrm{Z}_{\text {avg }}=140 \pm 1 \mathrm{~nm} \\
P d \mathrm{I}=0.13 \pm 0.02 \\
\mathrm{D}_{1}=155 \pm 5 \mathrm{~nm}(100 \%)\end{array}$ & $70 \pm 30$ \\
\hline $\begin{array}{c}\text { OLA modified } \\
\text { with } 1,3 \text {-alternate } \\
\text { tetraacid } 7\end{array}$ & $\begin{array}{c}\mathrm{Z}_{\text {avg }}=879 \pm 193 \mathrm{~nm} \\
\mathrm{PdI}=0.65 \pm 0.1 \\
\mathrm{D}_{1}=371 \pm 26 \mathrm{~nm} \\
(73 \%) \\
\mathrm{D}_{2}=5082 \pm 343 \mathrm{~nm} \\
(27 \%)\end{array}$ & $770 \pm 360$ & $\begin{array}{c}\mathrm{Z}_{\text {avg }}=603 \pm 104 \mathrm{~nm} \\
\mathrm{PdI}=0.25 \pm 0.05 \\
\mathrm{D}_{1}=405 \pm 61 \mathrm{~nm}(100 \%)\end{array}$ & $150 \pm 50$ & $\begin{array}{c}\mathrm{Z}_{\text {avg }}=97.9 \pm 0.5 \mathrm{~nm} \\
\mathrm{PdI}=0.25 \pm 0.01 \\
\mathrm{D}_{1}=98 \pm 0.5 \mathrm{~nm} \\
(100 \%)\end{array}$ & $30 \pm 10$ \\
\hline
\end{tabular}



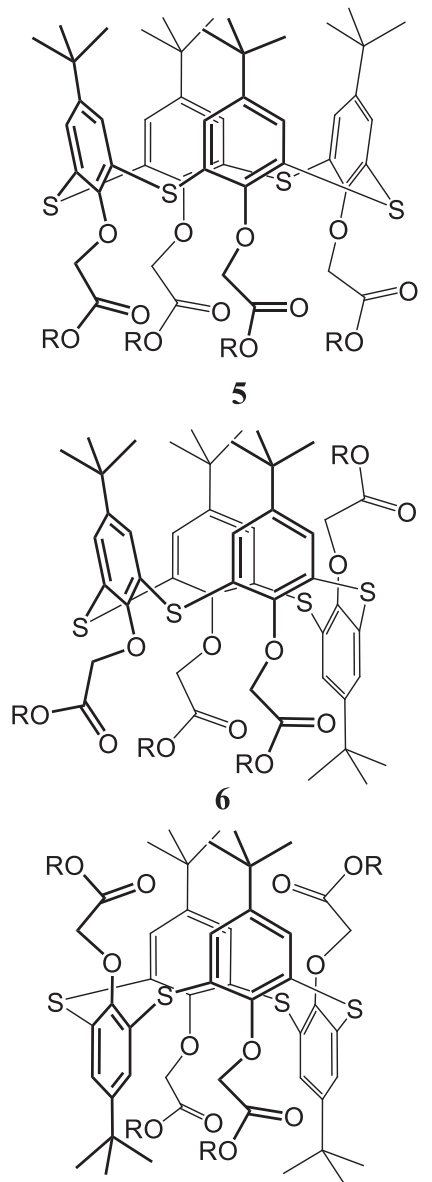

7

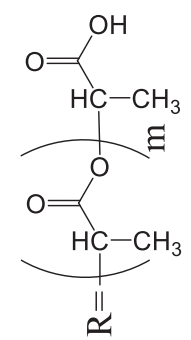

$\mathrm{CH}_{2} \mathrm{Cl}_{2}$, r.t., $\mathrm{t}=1 \mathrm{hr}$

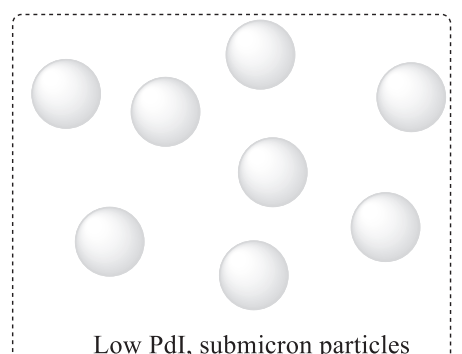

Low PdI, submicron particles

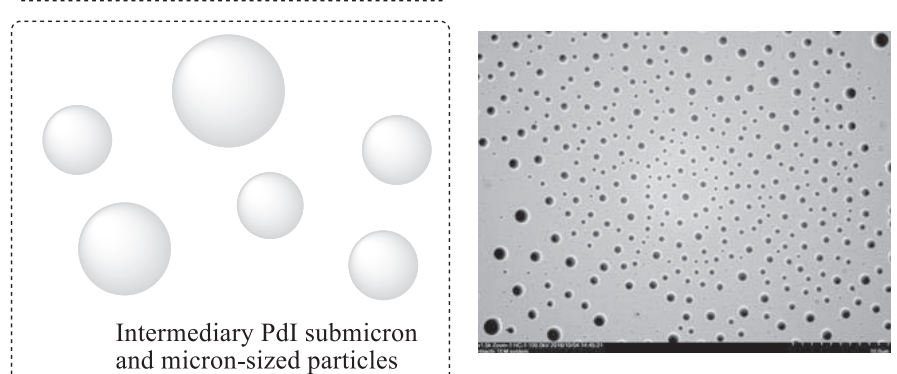

and micron-sized particles
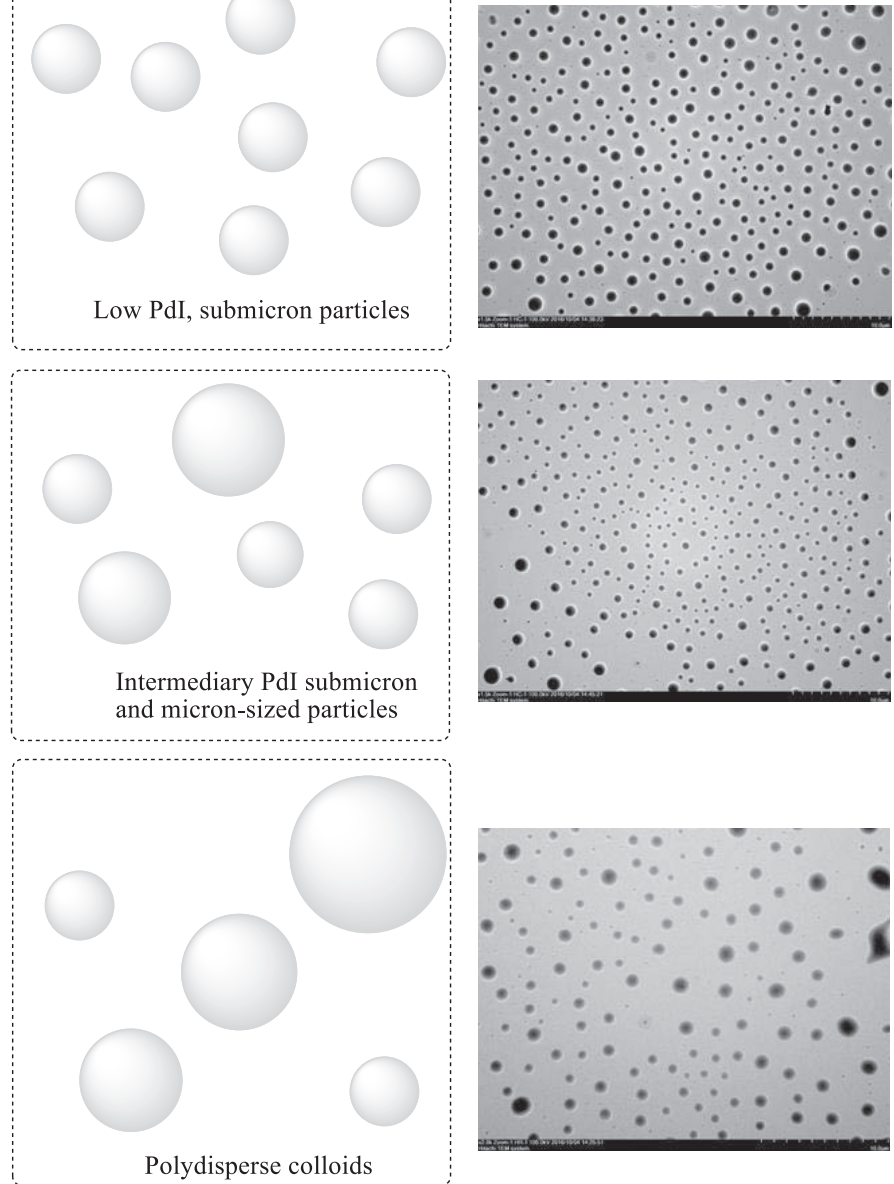

Figure 2. Derivatives 5-7 of OLA, modified with various conformers of thiacalix[4]arene; TEM images of the associates of 5-7, which are formed in result of self-assembly in dichloromethane with schematic depiction of associates formed.

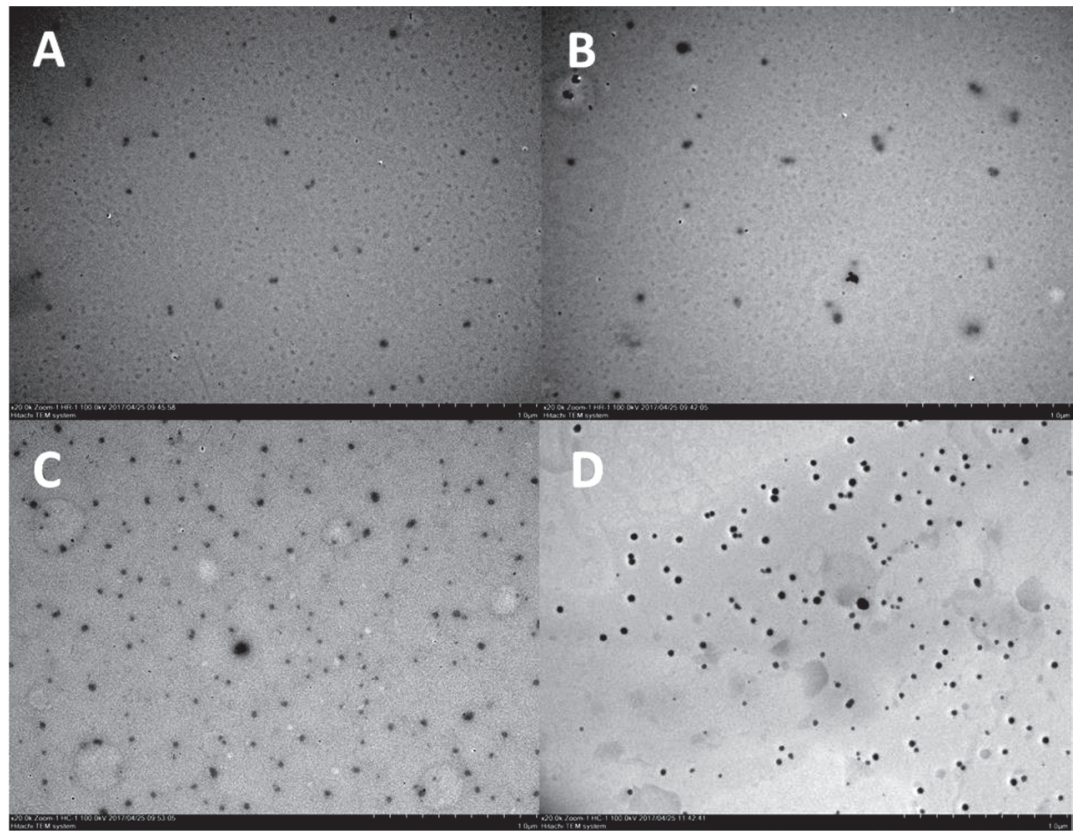

Figure 3. Images obtained by TEM method: A - self-assembly of the OLA 4 in acetone; B - nanoprecipitation of the OLA 4 in acetonewater system; $\mathrm{C}$ - self-assembly of the OLA modified with the derivative of thiacalix[4]arene in 1,3-alternate conformation 7 in acetone; $\mathrm{D}$ - nanoprecipitation of the OLA modified with the p-tert-butylthiacalix[4]arene derivative in 1,3-alternate conformation 7. 
$(\mathrm{PdI}=0.13-0.25)$. It was established by DLS that particles of minimal diameter $(98 \pm 0.5 \mathrm{~nm})$ were formed by the copolyester 7, modified with macrocycle in 1,3-alternate conformation (Table 1). The largest particles are formed by compound $\mathbf{5}$ with macrocyclic fragment in cone conformation $(191 \pm 11 \mathrm{~nm})$. In this case (similarly to selfassembly in acetone), non-modified OLA 4 formed large aggregates (Table 1). Data obtained by TEM method agree with the DLS data. Minimal particles were obtained for 7 $(30 \mathrm{~nm})$, largest aggregates by copolyester $\mathbf{5}(150 \mathrm{~nm})$.

Therefore, size decrease of associates is observed with increase of solvent polarity from self-assembly in dichloromethane to that in acetone and for nanoprecipitation from acetone to water. This is probably caused by different packing of self-associates formed. Possibly, associates swell in dichloromethane and acetone (forming loose packing), and almost do not swell in water. This leads to significant decrease in the size of the particles due to denser packing of the copolyester molecules.

\section{Thermal Behavior of Modified Oligolactic Acid}

The OLA 4 obtained and its derivatives 5-7 were studied by simultaneous thermogravimetry and differential scanning calorimetry. According to the thermogravimetric analysis data, the modification of the OLA with p-tertbutylthiacalix[4]arene derivatives leads to increase in the decomposition temperature of oligolactic acid. The only stage in the range of $246-385{ }^{\circ} \mathrm{C}$, corresponding to decomposition of oligolactic fragments in the compound 4 and of the products of its modification 5-7 (Figure 4) was observed on thermogram. ${ }^{[28]}$ It is interesting, that decomposition of the compound 7 occurs at the temperatures $\left(276-385^{\circ} \mathrm{C}\right)$ higher than those of non-modified OLA 4 $\left(246-343{ }^{\circ} \mathrm{C}\right)$ and thiacalixarene-modified OLA 5 and 6. The temperature related to the start of decomposition is $263{ }^{\circ} \mathrm{C}$ for both cone and partial cone conformations. It should be noted that the temperatures corresponding to the end of thermal decomposition are changing according to the same range. In the case of the OLA modified with thiacalix[4]arene derivative in 1,3-alternate conformation 7 the above temperature increases from 343 (for nonmodified OLA 4) to $381{ }^{\circ} \mathrm{C}$, for cone 5 and partial cone $\mathbf{6}$ conformations the observed temperatures are close to the temperatures characterizing the OLA (340.3 and 349.3, respectively)

Endo-peaks on thermograms recorded by differential scanning calorimetry corresponded to thermal decomposition of the OLA $4\left(301{ }^{\circ} \mathrm{C}\right)$, and the oligolactic acids 5-7 modified with thiacalixarene derivatives in cone $\left(31{ }^{\circ} \mathrm{C}\right)$, partial cone $\left(313^{\circ} \mathrm{C}\right)$ and 1,3 -alternate $\left(326^{\circ} \mathrm{C}\right)$ conformations. These values correspond to the middle of thermal decomposition estimated by the Marsh procedure (296, 303, $307,327{ }^{\circ} \mathrm{C}$, correspondingly). All that mentioned above confirms most significant effect of the thiacalixarene in 1,3-alternate conformation on thermal stability of copolyesters obtained. Such a significant difference in thermal stability of $\mathbf{5}$ and $\mathbf{6}$ can be explained by symmetric geometry of the macrocyclic fragment (1,3-alternate) which forms a «knot element» in the OLA structure. To confirm, that the thermal stabilization is related to covalent binding of the OLA with

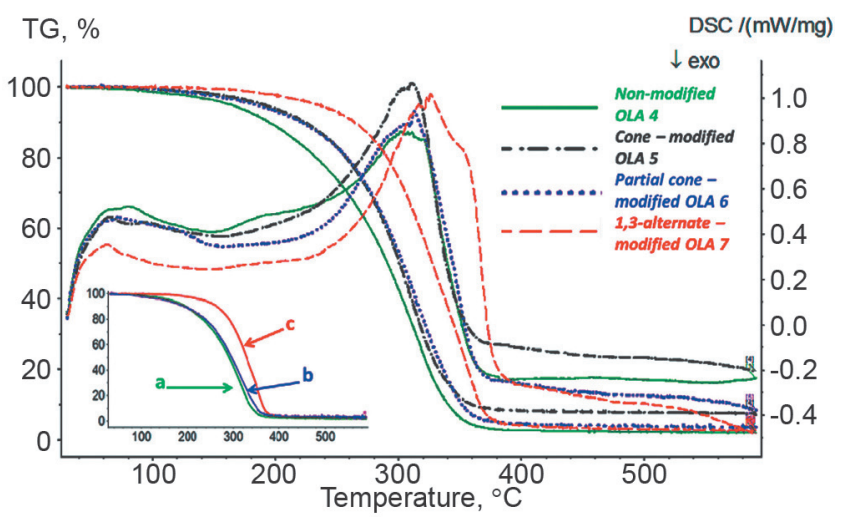

Figure 4. TGA/DSC diagrams of OLA 4 and copolyesters of OLA with $p$-tert-butylthiacalix[4]arene in various spatial conformations 5-7; the insets show mass loss of oligolactic acid 4 (a), mechanical mixture of $\mathbf{4}$ with 1,3-alternate $\mathbf{3}$ (b) and copolyester 7 (c).

macrocycle but not its possible influence as a filler, additional experiment was carried out. The solutions of tetraacid $\mathbf{3}$ (1,3-alternate) and oligolactic acid 4 were mixed and evaporated out at $60{ }^{\circ} \mathrm{C}$, i.e. in conditions excluding esterification of tetracarboxylic derivative of $p$-tert-butylthiacalix[4]arene with oligolactic acid. Thermogravimetric curve of the mixture obtained was identical to the curve for 4 (thermal decomposition also started at $246{ }^{\circ} \mathrm{C}$ ) (Figure 4). Therefore, the covalent modification with thiacalix[4]arene derivatives led to increase in the OLA thermal stability.

\section{Conclusions}

Therefore, new approach to the modification of the oligolactic acid with p-tert-butylthiacalix[4]arene based on creating homogeneous media for copolycondensation of the OLA with tetracarboxylic derivatives of macrocycle has been realized. The derivatives of thiacalixarene were used in three different spatial conformations. Copolyesters obtained are capable to form nano-sized self-associates as was shown by DLS and TEM methods. Their aggregation properties depend on the configuration of the macrocyclic fragment of copolyester and polarity of the solvent. Increase of solvent polarity leads to change in packing of copolyesters resulted in lower size of aggregates formed. Thermal stability of macrocycle-bonded oligolactides was studied by simultaneous TGA-DSC. Modification of the oligolactic acid with the thiacalixarene fragment in 1,3-alternate conformations increases its thermal stability most significantly. This results in a high increase of decomposition temperature compared to initial oligolactide.

Acknowledgements. The work was supported by the Russian Science Foundation (No. 16-13-00005).

\section{References}

1. Gao C., Wang Y., Zhu W., Shen Zh. Chin. J. Polym. Sci. 2014, $32,1431-1441$. 
2. Belali S., Reza Karimi A., Hadizadeh M. Polymer 2017, 109, 93-105.

3. Wu R., Al-Azemi T.F., Bisht K.S. RSC Adv. 2014, 4, 1686416870.

4. Garlotta D. J. Polym. Environ. 2001, 9, 63-84.

5. Maeda H., Kasuga T. Acta Biomaterialia 2006, 2, 403-408.

6. Chu C.R., Coutts R.D., Yoshioka M., Harwood F.L., Monosov A.Z., Amiel D. J. Biomed. Mater. Res. 1995, 29, 1147-1154.

7. Félix Lanao R.P., Leeuwenburgh S.C.G., Wolke J.G.C., Jansen J.A. Biomaterials 2011, 32, 8839-8847.

8. Mehanny M., Hathout R.M., Geneidi A.S., Mansour S. J. Biomed. Mater. Res. Part A 2017, 105A, 1433-1445.

9. Shen J., Hao A., Du G., Zhang H., Sun H. Carbohydr. Res. 2008, 343, 2517-2522.

10. Morohashi N., Narumi F., Iki N., Hattori T., Miyano S. Chem. Rev. 2006, 106, 5291-5316.

11. Kumar R., Lee Y.O., Bhalla V., Kumar M., Kim J.S. Chem. Soc. Rev. 2014, 43, 4824-4870.

12. Vavilova A.A., Nosov R.V., Mostovaya O.A., Stoikov I.I. Macroheterocycles 2016, 9, 294-300.

13. Puplampu J.B., Yakimova L.S., Vavilova A.A., Rizvanov I.K., Stoikov I.I. Macroheterocycles 2015, 8, 75-80.

14. Mostovaya O.A., Agafonova M.N., Galukhin A.V., Khayrutdinov B.I., Islamov D., Kataeva O.N., Antipin I.S., Konovalov A.I., Stoikov I.I. J. Phys. Org. Chem. 2014, 27, 57-65.

15. Trush V.V., Kharchenko S.G., Tanchuk V.Y., Kalchenko V.I., Vovk A.I. Org. Biomol. Chem. 2015, 13, 8803-8806.
16. Padnya P.L., Andreyko E.A., Mostovaya O.A., Rizvanov I.Kh., Stoikov I.I. Org. Biomol. Chem. 2015, 13, 58945904.

17. Nosov R.V., Stoikov I.I. Macroheterocycles 2015, 8, 120-127.

18. Nosov R.V., Stoikov I.I. Macroheterocycles 2014, 7, 345-350.

19. Stoikov I.I., Mostovaya O.A., Yakimova L.S., Yantemirova A.A., Antipin I.S., Konovalov A.I. Mendeleev Commun. 2010, 20,359-360.

20. Khomich E., Kashapov M., Vatsouro I., Shokova E., Kovalev V. Org. Biomol. Chem. 2006, 4, 1555-1560.

21. Gorbatchuk V.V., Porfireva A.V., Stepanova V.B., Kuzin Yu.I., Evtugyn V.G., Shamagsumova R.V., Stoikov I.I., Evtugyn G.A. Sens. Actuators, B 2017, 246, 136-145.

22. Harshe Y.M., Storti G., Morbidelli M., Gelosa S., Moscatelli D. Macromol. React. Eng. 2007, 1, 611-621.

23. Perego G., Cella G.D., Bastioli C. J. Appl. Polym. Sci. 1996, $59,37-43$.

24. Mittal G., Sahana D.K., Bhardwaj V., Kumar M.R. J. Controlled Release 2007, 119, 77-85.

25. Yushkova E.A., Stoikov I.I. Langmuir 2009, 25, 4919-4928.

26. Fessi H., Puisieux F., Devissaguet J.Ph., Ammoury N., Benita S. Int. J. Pharm. 1989, 55, R1-R4.

27. Morales-Cruz M., Flores-Fernández G.M., Morales-Cruz M., Orellano E.A., Rodriguez-Martinez J.A., Ruiz M., Griebenow K. Results in Pharma Sciences 2012, 2, 79-85.

28. Chen Y., Yang Y., Su J., Tan L., Wang Y. React. Funct. Polym. 2007, 67, 396-407. 